\title{
A NEW WILD LIFE RESERVE IN CEYLON
}

\author{
Gal Oya National Park and Sanctuaries
}

\author{
By C. E. Nonnis
}

\section{Secretary, The Wild Life Protection Society of Ceylon}

In 1949 work commenced on the most ambitious development scheme so far carried out in Ceylon, for the opening up of some 400,000 acres of forest for agricultural and industrial purposes. The whole scheme comes under the auspices of an autonomous body "The Gal Oya Development Board". A dam has been built across the Gal Oya, which is a perennial river, to form a vast reservoir, the largest in the island, covering some $35 \cdot 8$ square miles. Large tracts of forest-land have been cleared for cultivation and settlement and a net-work of roads and distributory channels has been constructed.

As the development of the valley progressed, so did the destruction of wild life by the increasing population of settlers and others connected with the working of such a huge scheme. Shooting for sport, meat and defence of crops assumed such alarming proportions, that the authorities decided it was time to provide a sanctuary for all forms of wild life. Accordingly, on the 12th February, 1954, a considerable portion of the valley was, by law, set apart for this purpose.

Luckily with such a scheme it is necessary to provide a natural watershed, uninhabited so as to avoid erosion and possible silting up of the reservoir.

A national park covering over 100 square miles now skirts the edge of the reservoir. 'This park consists of more or less flat country, 300-500 feet above sea-level, with scattered rocky hills rising to over 2,000 feet. These hills are the remnants of a mountain range croded thousands of years ago. Roughly a quarter of the national park is covered by forest of the dry, evergreen type; the rest is beautiful park-like savannah forest, scattered with trees and a carpet of green grass. This provides ideal country for spotted deer (chital), sambar and buffalo and the elephant which still roams the area. Other animals to be found are sloth bear, lcopard and wild pig.

Except for a small settlement of Veddah families on the northern border, the national park is entirely free of human habitations. 'These Veddahs, who shortly will be evacuated, are the remnants of an ancient tribe of jungle dwellers. The park, which forms a belt of forest round the reservoir, plays an 
important role in conserving the soil-the permanent plant cover reducing washaway to a minimum.

This national park, although situated within the dry zone of Ceylon has an advantage over the other parks with similar climatic conditions, owing to the perennial supply of water. It is hoped this may cause animals to migrate from areas in which, during the dry weather, water is a difficulty. At present the park is only accessible on foot but it is expected that a circular motor road will be made.

Entry into the park is by permit, obtainable for a very low fee from the Development Board's office at Inginiyagalla; a small but well equipped bungalow in the vicinity of the park provides accommodation for visitors.

A further $142 \frac{1}{2}$ square miles have been set aside in three separate sanctuaries, but the whole reserve, including the national park, forms an almost compact block. The three sanctuaries are :

(a) The Senanayalie Samudra Sanctuary, comprising the $35 \cdot 8$ square miles of the water itself. This large shect of water has many small islets scattered over its surface, which are becoming the homes of many birds. Even at this early stage a great number of different birds can be seen and when the edges become overgrown with swamp vegetation a greater variety should be present. For the convenience of visitors the authorities provide launches and motor-boats to take them round the islets. The swamp crocodile (Crodilus palustris) has found its way to this sanctuary and can be seen basking on rocks in the quieter corners. The waters contain a varied selection of fish, some of which have been introduced whilst others are indigenous. The commonest are the fresh-water shark, Wallago attu valeya, carp, gourami and Tilapia mossambica.

This reservoir offers one of the most beautiful views to be found in Ceylon, especially at dawn and sunset.

(b) The South Western Sanctuary, consisting of 59 square miles is a protective zone around the south and south-western boundary of the national park. 'The vegetation is very similar to that of the park itself, but there are scattered clearings for cultivation used by some 2,000 villagers who dwell within this sanctuary. The Pallang Oya, which flows through the sanctuary, will shortly be dammed for flood prevention and water storage so that a considerable portion of the area will be inundated. It is the policy of the Development Board to persuade the inhabitants to take up residence as colonists within the newly 
developed and irrigated areas in order to leave this sanctuary uninhabited by humans.

(c) The North Eastern Sanctuary, consisting of $47 \cdot 7$ square miles lies to the north east of the national park. The vegetation is beautiful park country, much favoured by spotted deer and sambar. Elephant also will be found in this area at certain times of the year, in quite large herds. This area includes two "tanks" (small lakes) which used to be sanctuaries, but were abolished

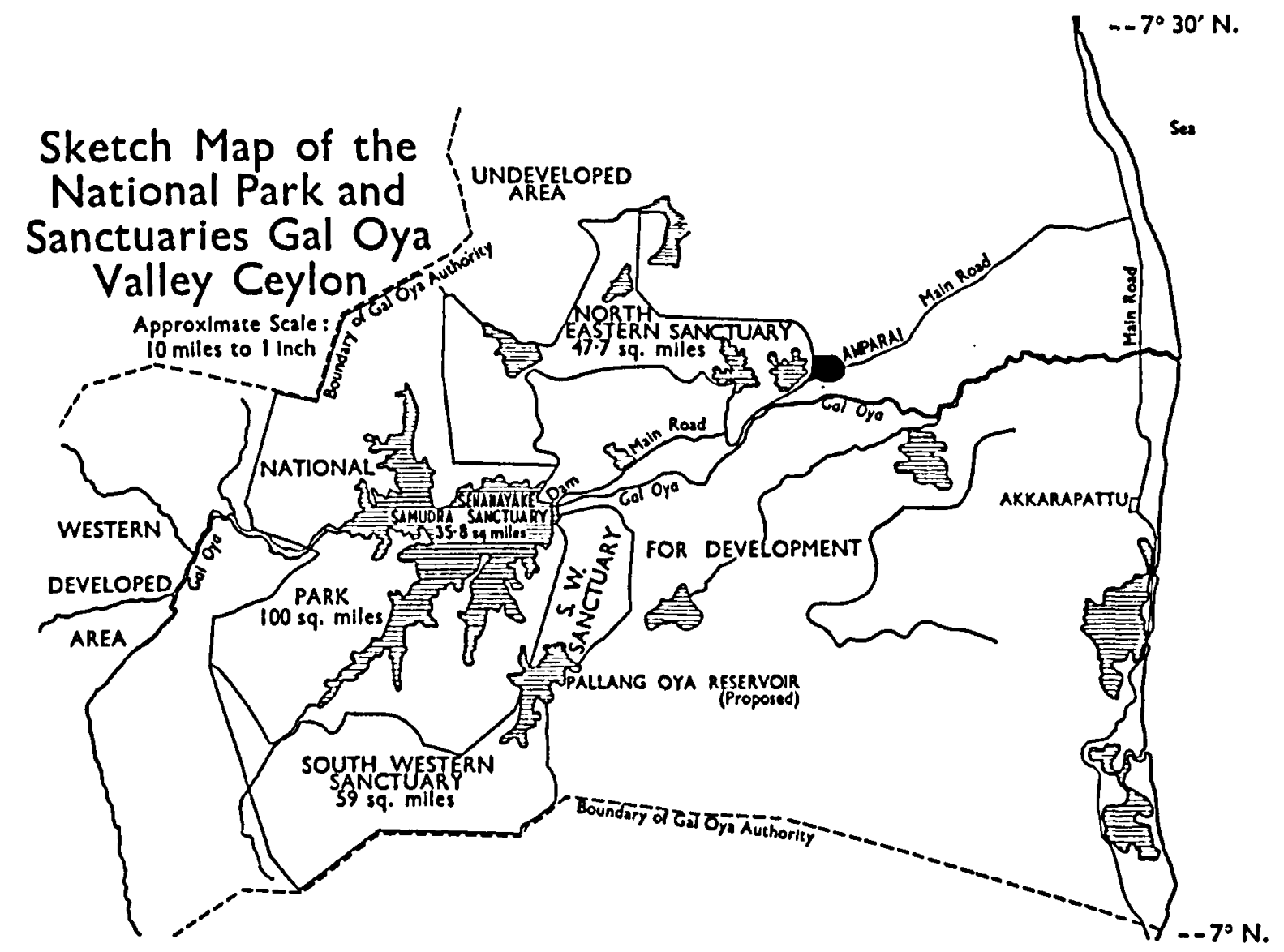

as such when the Development Board took charge. It is most gratifying to see that they have been returned to their original status, as they are greatly favoured nesting grounds for many species of birds.

The administration of the national park and sanctuaries is the responsibility of the Development Board's forest branch, which has a special section for the protection of wild life. In addition an Advisory Committee has been formed to assist in the administration of these reserves. The law does not permit any shooting or hunting to take place within a national park, but it has been found necessary to permit shooting for the protection of food crops within the confines of the sanctuaries. This is 
regrettable, but unavoidable until the inhabitants can be persuaded to take up their residence elsewhere.

The administration is faced with a constant conflict between the cultivator and the marauding elephant; this is a grave problem as the cultivator invariably uses his gun, generally inflicting wounds and making the animal a rogue. Several cases have been reported recently in which inhabitants have been attacked and killed by elephants. These animals have had to be officially proclaimed "rogues" and destroyed.

Elephants are animals of habit and will occupy traditional areas for their feeding, as their ancestors have done for generations. Many persuasive methods, such as burning fires, sounding sirens at night, electrical and wooden fences and lighting of crackers from watch huts, have been tried and are in use. Perhaps, before long, elephants will learn they must move to the safer confines of the national park and that their reign in the valley must come to an end.

This new reserve proves that irrigation schemes can benefit the protection of wild life if tackled in the right way, for natural cover of vegetation in the catchment areas is necessary for the success of the scheme itsclf.

I am greatly indebted to Dr. R. W. Szechowycz, the Board's Chief Forest Officer, for the information he supplied to enable me to compile this short article.

\section{HOW A LEOPARD KILLS HIS PREY}

\section{(Translations from reports of the staff of the Ceylon Wild Life Department)}

By Game Guard W. L. A. Andris of Yala Range

I was on my way to Yala one evening and, near Wilapalawewa, I noticed a leopard lying beneath a tree. I took cover and watched. The leopard was lying on its belly with its forelegs stretched forward and its gaze was fixed on a herd of spotted decr which was grazing about 100 yards away. It kept tossing its tail about but its head and body were motionless. The unsuspecting deer were nibbling the grass and moving slowly forward towards the lcopard. As they appronched closer and closer the leopard gradually brought its forclegs back close to its body and kept its head low down, but the occasional twitching of the tail continued. When the deer were within 20 yards the 